\title{
Method for Adjusting Results of Pharmacoeconomic Studies from Country to Country Using Bayesian Statistics
}

\author{
Slobodan M. Janković, Marina J. Kostić, Jasmina R. Milovanović \\ Faculty of Medical Sciences, University of Kragujevac, Kragujevac, Serbia
}

\section{SUMMARY}

Introduction: Key problems when transferring results of pharmacoeconomic studies between countries are: relative infrequency of observational design, utilization of unreliable estimates of input parameters in many of modelling studies, not reporting variability of the study outputs (e.g. ICER, net monetary benefit) in a publication, and large differences in costs of healthcare services and drugs from country to country.

Aim: The aim of this study was to estimate Incremental Cost-effectiveness Ratio (ICER) of denosumab vs. alendronate for treatment of osteoporosis in postmenopausal women in Serbia, using results of published pharmacoeconomic studies in United States of America (USA) and Japan.

Material and Methods: The estimate of the ICER was made through the following steps: (1) scaling the ICER of the published studies to Serbian healthcare milieu using unit costs in Serbia, USA and Japan; (2) defining prior distribution of the ICER using adjusted results of the earlier published study; (3) defining sampling distribution of the ICER using adjusted results of the next published study; (4) estimating posterior distribution of the ICER and calculating the most probable values the ICER with Bayesian statistics.

Results: The ICER of the prior distribution was 572,787.00 RSD, with $99 \%$ confidence interval from 1,116.00 to 998,051.00 RSD, and that of the sampling distribution 706,057.00 RSD, with $99 \%$ confidence interval from 1,122.00 to $999,308.00$ RSD. The most probable ICER value from the posterior distribution was $752,912.00$ RSD, with $99 \%$ confidence interval from 667,631.00 to 771,552.07 RSD. The estimated ICER was below one Gross Domestic Product (GDP) of Serbia per capita (the 2019 value: 780,063.60 RSD).

Conclusions: Denosumab should be considered cost-effective in Serbia if one to three GDPs/capita/Quality Adjusted Life Year (QALY) gained is taken as the upper limit of willingness to pay by Serbian Health Insurance Fund.

Keywords: Bayesian statistics, pharmacoeconomic studies, Incremental Cost-effectiveness Ratio, estimate 


\section{INTRODUCTION}

Studies in Pharmacoeconomics are always population- and country-specific, since inputs in all calculations depend on perspective of local payer, local epidemiological data, availability of comparators and local prices of healthcare services and drugs [1]. Usual approach when a pharmacoeconomic (PE) study performed in one country is intended to be applied to another country is to correct resource utilization rate, prices of healthcare services and prices of drugs [2]. However, there is a number of practical problems when employing such approach: relative infrequency of observational studies which are the most reliable, high uncertainty of input parameters of many of modelling studies, not reporting variability of the study inputs and outputs (e.g. ICER, net monetary benefit) in a publication, unavailability of the same or similar comparators and large disproportionalities among costs of healthcare services and drugs from country to country [3].

If there are several studies on the same topic from one or several countries that should be applied to a particular country, they usually differ in quality of data and methodology, and summation of their inputs and outputs is not straightforward. Various methods of weighting data are used, but sometimes differences in design are precluding such approach[4]. In such situations use of Bayesian statistical methods could be particularly rewarding [5], since single studies are sequentially used as sources of "prior" and „sampling” distributions of certain input or output parameter values, gradually improving estimate of $\mathrm{PE}$ results for the target country. However, in order to employ Bayesian statistics for these purposes and handle distributions of data instead of single central tendency measures, developing calculators is necessary due to complexity.

\section{AIM}

The aim of this study was to demonstrate the use of specially designed Bayesian calculator for estimation of Incremental Costeffectiveness Ratio (ICER) of denosumab vs. alendronate for treatment of osteoporosis in postmenopausal women in Serbia using results of published pharmacoeconomic studies in United States of America (USA) and Japan.

\section{MATERIAL AND METHODS}

This study is an academic, in silico study of drugs after marketing authorization (phase IV). Two previous studies investigated the cost-effectiveness of the biological drugs for osteoporosis denosumab, comparing it with alendronate in postmenopausal women. Denosumab is a human monoclonal antibody against RANKL, a protein that stimulates osteoclasts to resorb the bones and cause osteoporosis [6]. Modeling study of Parthan and associates [7] conducted in the USA (Markov model) found the value of ICER for denosumab vs. alendronate in postmenopausal women with osteoporosis to be $\$$ US85,100/Quality Adjusted Life Year (QALY) gained, while the study of Mori and associates [8] from Japan (also Markov model-based study) calculated ICER for denosumab vs. alendronate in the same population of $\$ 25,700 /$ QALY gained.

Adjusting results of these two studies for Serbian conditions was made through the following steps:

(1) using Serbian unit costs of drugs and healthcare services the ICERs of the published studies were scaled to Serbian circumstances and expressed in local currency (Serbian dinars - RSD);

(2) the scaled result of the earlier study (Parthan et al) was used to determine the prior distribution of the ICER, and the scaled result of the study from Japan was used to determine sampling distribution of the ICER;

(3) Bayesian calculator specially designed by the first author (Janković SM, used for the first time, available on-demand) for this purpose was used to estimate the posterior distribution of the ICER and calculate from it the most probable values of ICER for Serbia. The first step vas done by the following scaling formula:

$$
\begin{aligned}
& \text { ICER in Serbia }(R S D)=(A \times C \times(F 1 / F 2)+ \\
& A \times D \times(G 2 / G 1)+A \times E \times(H 2 / H 1)) \times B
\end{aligned}
$$

The second step was to determine prior and sampling gamma distributions of the probability density of ICER; alpha and beta hyperparameters of prior and sampling gamma distributions were calculated according to the method described by Gelman and associates [9]. The estimate of alpha and beta parameters of posterior distribution was made by multiplying prior gamma density distribution with appropriate likelihood function [10]. All cal-

\section{Equation 1.}

$A=$ ICER in US dollars published in a cost-effectiveness study; $B=$ exchange rate US dollar Serbian dinar (RSD);

$C, D$, and $E=$ fraction of total costs of treatment with denosumab made by drugs, hospitalizations and nursing homes, respectively;

$F 1 / F 2, G 1 / G 2$ and $H 1 / H 2=$ ratios of unit costs of drugs, hospitalizations, and nursing homes, respectively, where index ,1" denotes Serbia and „2" other country where previous PE study was done. 
Figure 1. The prior gamma distribution, the sampling gamma distribution, and the posterior gamma distribution of probability density.

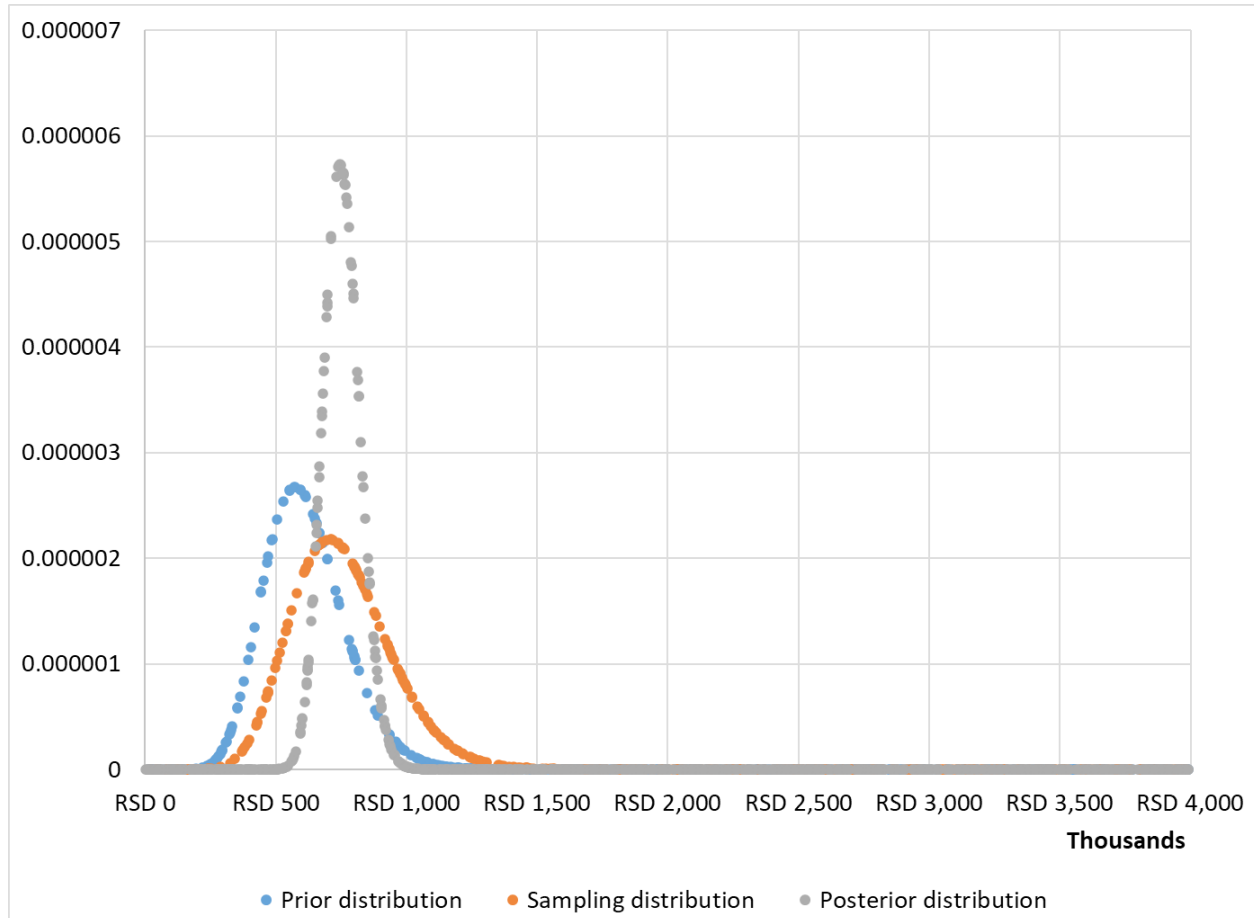

culations and graphs were made in the third step, by the calculator "Bayesian statistics” made in Excel 2016 by the first author of this article. Parthan's study was used to estimate of the prior distribution, and Mori's study for estimating the sampling distribution.

\section{RESULTS}

The prior gamma distribution, the sampling gamma distribution, and the posterior gamma distribution are graphically represented in Figure 1.

The estimates of ICERs from prior, sampling, and posterior distributions with their $99 \%$ confidence intervals are shown in Table 1. According to the estimate of ICER from the posterior distribution of probability density, denosumab could be considered a cost-effective strategy in comparison to alendronate, because the ICER is below one Gross Domestic Product (GDP) per capita, per QALY gained in Serbia (780,063.60 RSD in 2019.) [11].

\section{DISCUSSION}

According to this method, denosumab was found to be cost-effective for the treatment of postmenopausal osteoporosis in Serbia if 1-3 GDPs/capita/QALY gained is taken for willingness to pay limit. The described method involved published pharmacoeconomic studies through an iterative approach: previous posterior distribution is used as prior distribution for the next step, and so on, until all published studies were exploited; the iterations could be chronological or according to the sample size (or quality of the evidence?).

Denosumab was confirmed as a cost-effective option for the treatment of postmenopausal osteoporosis in all countries where it had been investigated by PE studies. The study based on theMarkov model was performed in Thailand, where denosumab was compared to alendronate or no pharma-
Table 1. The ICERs estimated from the prior, sampling and posterior distributions.

\begin{tabular}{|c|c|c|}
\hline The estimate & ICER & Confidence interval (99\%) \\
\hline $\begin{array}{l}\text { According to the PRIOR distribution of } \\
\text { probability density (the first study) }\end{array}$ & 572,787.00 RSD/QALY & $\begin{array}{c}1,116.00-998,051.00 \mathrm{RSD} / \\
\text { QALY }\end{array}$ \\
\hline $\begin{array}{l}\text { According to the SAMPLING distribution of } \\
\text { probability density (the second study) }\end{array}$ & 706,057.00 RSD/QALY & $\begin{array}{c}1,122.00-999,308.00 \mathrm{RSD} / \\
\text { QALY }\end{array}$ \\
\hline $\begin{array}{l}\text { According to the POSTERIOR distribution of } \\
\text { probability density }\end{array}$ & 752,912.00 RSD/QALY & $\begin{array}{c}667631.00 \text { RSD - } 771552.07 \\
\text { RSD/QALY }\end{array}$ \\
\hline
\end{tabular}


cologic therapy in menopausal women with osteoporosis with a high risk of vertebral fractures: it was cost-effective when compared to no treatment if the willingness to pay was set to $1 \mathrm{GDP} /$ capita/QALY gained, and also when compared to alendronate if the willingness to pay was set to $3 \mathrm{GDP} /$ capita/QALY gained [12]. Although developed countries with expensive healthcare services like Japan show higher nominal ICER values for denosumab when compared to oral bisphosphonates, it is still cost-effective because the willingness to pay is also much higher. The study of Yoshizawa and associates showed by means of Markov model [13] that denosumab is cost-effective, with ICER of US\$40,241/QALY, which is still below threshold of one GDP per capita/QALY, which in Japan amounts to US\$50,000/QALY. Denosumab was even more cost-effective for a subgroup of patients older than 75 years of age with a history of earlier vertebral fracture. Similar results were reported by modelling studies conducted in Swedish [14] and Canadian [15] settings. In both countries, the ICER of denosumab vs. oral bisphosphonates for the treatment of postmenopausal osteoporosis was below one GDP per capita/QALY, and the lowest ICER was recorded for the subgroup with a high risk of fracture and low expected adherence to oral treatments.

One of the reasons for beneficial cost-effectiveness ratio of denosumab to oral bisphosphonates is improved adherence to therapy. Therapy of osteoporosis in menopause lasts for years, even decades, and it requires considerable discipline from patients who have to take oral bisphosphonates regularly daily or weekly for such long period of time. A meta-analysis of 16 studies first demonstrated improved adherence with denosumab over oral bisphosphonates, and then confirmed denosumab as being cost-effective option in all postmenopausal patients with osteoporosis, and cost-saving option in patients over 75 years of age, with history of previous fractures, lower T-scores, and multiple risk factors [16].

Unlike bisphosphonates, which reach a plateau of bone mineral density increase after 2-3 years, denosumab produces a steady increase in bone mineral density as long as it is administered. However, this advantage was not yet proven associated with a decrease in the rate of fractures when compared to bisphosphonates; besides, after stopping the administration of denosumab there is an in- creased risk of vertebral fractures, which could be prevented if bisphosphonates are immediately re-instituted. Therefore, long-term treatment with denosumab is the most effective and safe option for the time being [17].

There is an important limitation of our study has, which is related to scaling of ICER values from other studies to Serbian circumstances [1]. Equation 1 works well if differences among unit prices of healthcare services among the countries are less than fivefold; higher differences lead to a disproportionate decrease in transformed ICER values. However, such high differences are found only when prices are administratively regulated, ignoring real market values, which are much higher and usually in use by healthcare providers independent from the state.

\section{CONCLUSION}

Denosumab should be considered cost-effective in Serbia if one to three GDPs/capita/ QALY gained is taken as upper limit of willingness to pay by Serbian Health Insurance Fund.

\section{CONFLICTS OF INTEREST}

All authors declare no conflict of interest.

\section{ACKNOWLEDGEMENT}

This study was partially supported by the Grant No 175007 from Ministry of Education, Science and Technological Development, Republic of Serbia.

\section{REFERENCES}

1. Mason JM, Mason AR. The generalisability of pharmacoeconomic studies: issues and challenges ahead. PharmacoEconomics. 2006;24(10):937-45.

2. Ademi Z, Tomonaga Y, van Stiphout J, Glinz D, Gloy V, Raatz H, et al. Adaptation of cost-effectiveness analyses to a single country: the case of bariatric surgery for obesity and overweight. Swiss Med Wkly. 2018;148:w14626.

3. Augustovski F, Iglesias C, Manca A, Drummond M, Rubinstein A, Martí SG. Barriers to generalizability of health economic evaluations in Latin America and the Caribbean region. PharmacoEconomics. 2009;27(11):919-29.

4. Stawowczyk E, Kawalec P. A Systematic Review of the Cost-Effectiveness of Biologics for Ulcerative Colitis. PharmacoEconomics. 2018 Apr;36(4):419- 
34.

5. Skrepnek GH. The contrast and convergence of Bayesian and frequentist statistical approaches in pharmacoeconomic analysis. PharmacoEconomics. 2007;25(8):649-64.

6. Deeks ED. Denosumab: A Review in Postmenopausal Osteoporosis. Drugs Aging. 2018 Feb;35(2):163-73.

7. Parthan A, Kruse M, Yurgin N, Huang J, Viswanathan HN, Taylor D. Cost effectiveness of denosumab versus oral bisphosphonates for postmenopausal osteoporosis in the US. Appl Health Econ Health Policy. 2013 Oct;11(5):485-97.

8. Mori T, Crandall CJ, Ganz DA. Cost-effectiveness of denosumab versus oral alendronate for elderly osteoporotic women in Japan. Osteoporos Int J Establ Result Coop Eur Found Osteoporos Natl Osteoporos Found USA. 2017 May;28(5):1733-44.

9. Gelman A, Carlin JB, Stern HS, Dunson DB, Vehtari A, Rubin DB. Bayesian Data Analysis. 3rd ed. USA: CRC Press, Taylor \& Francis Group; 2014.

10. Fink D. A Compendium of conjugate priors. [Internet]. 1997. 1-47. p. Available from: https:// www. johndcook.com/CompendiumOfConjugatePriors.pdf

11. Претрага дисеминационе базе [Internet]. [cited 2021 Mar 7]. Available from: https://data.stat. gov.rs / Home/Result/09020101?languageCode=srCyrl

12. Pongchaiyakul C, Nanagara R, Songpatanasilp T, Unnanuntana A. Cost-effectiveness of denosumab for high-risk postmenopausal women with osteoporosis in Thailand. J Med Econ. 2020 Jul;23(7):77685.

13. Yoshizawa T, Nishino T, Okubo I, Yamazaki M. Cost-effectiveness analysis of drugs for osteoporosis treatment in elderly Japanese women at high risk of fragility fractures: comparison of denosumab and weekly alendronate. Arch Osteoporos. 2018 Aug 29;13(1):94.

14. Jönsson B, Ström O, Eisman JA, Papaioannou A, Siris ES, Tosteson A, et al. Cost-effectiveness of Denosumab for the treatment of postmenopausal osteoporosis. Osteoporos Int J Establ Result Coop Eur Found Osteoporos Natl Osteoporos Found USA. 2011 Mar;22(3):967-82.

15. Chau D, Becker DL, Coombes ME, loannidis G, Adachi JD, Goeree R. Cost-effectiveness of denosumab in the treatment of postmenopausal osteoporosis in Canada. J Med Econ. 2012;15 Suppl 1:3-14.

16. Morizio P, Burkhart JI, Ozawa S. Denosumab: A Unique Perspective on Adherence and Cost-effectiveness Compared With Oral Bisphosphonates in Osteoporosis Patients. Ann Pharmacother. 2018 Oct;52(10):1031-41.
17. Anastasilakis AD, Polyzos SA, Makras P. THERAPY OF ENDOCRINE DISEASE: Denosumab vs bisphosphonates for the treatment of postmenopausal osteoporosis. Eur J Endocrinol. 2018 Jul;179(1):R31-45. 


\title{
Metod za prilagođavanje rezultata farmakoekonomskih studija od zemlje do zemlje pomoću Bajezijanske statistike
}

\author{
Slobodan M. Janković, Marina J. Kostić, Jasmina R. Milovanović \\ Fakultet medicinskih nauka, Univerzitet u Kragujevcu, Kragujevac, Srbija
}

\section{KRATAK SADRŽAJ}

Uvod: Prilikom prenošenja rezultata farmakoekonomskih studija od zemlje do zemlje postoji nekoliko problema: mali broj opservacionih studija koje se odlikuju najvećom tačnošću, korišćenje nepouzdanih procena ulaznih parametara kod studija sa modeliranjem, neprikazivanje varijabilnosti ishoda studije (npr. ICER, neto monetarni benefit) u publikacijama, i velike razlike u cenama zdravstvenih usluga i lekova između zemalja.

Cilj: Cilj ove studije je bio da proceni Inkrementalni odnos troškova i efekata (ICER) denosumaba i alendronata u lečenju osteoporoze žena u postmenopauzi koje žive u Srbiji, korišćenjem rezultata publikovanih farmakoekonomskih studija sprovedenih u Sjedinjenim Američkim Državama (S.A.D.) i Japanu.

Metodologija: Procena ICER-a napravljena je kroz sledeće korake: (1) skaliranje ICER-a objavljenih studija prema srpskom zdravstvenom miljeu koristeći jedinične troškove u Srbiji, SAD-u iJapanu; (2) definisanjeprethodnedistribucije ICER-a koristeći prilagođene rezultate studije objavljene ranije; (3) definisanje „distribucije uzorka” ICER-a koristeći prilagođene rezultate sledeće objavljene studije; (4) procena naknadne distribucije ICER-a i izračunavanje najverovatnijih vrednosti ICER-a pomoću Bajezijanske statistike.

Rezultati: ICER prethodne distribucije iznosio je 572.787,00 RSD, sa intervalom pouzdanosti 99\% od 1.116,00 do 998.051,00 RSD, a „distribucije uzorka” 706.057,00 RSD, sa $99 \%$ intervalom pouzdanosti od 1.122,00 do 999.308,00 RSD. Najverovatnij avrednost ICER-a iz naknadne raspodele bila je 752.912,00 RSD, sa $99 \%$ intervalom pouzdanosti od 667.631,00 do 771.552,07 RSD. Procenjeni ICER bio je ispod jednog bruto domaćeg proizvoda (BDP) Srbije po stanovniku (vrednost za 2019. godinu 780.063,60 RSD).

Zaključak: Denosumab treba smatrati isplativim u Srbiji ako se jedan od tri BDP-a po glavi stanovnika i po stečenoj godini života prilagođenoj za kvalitet (QALY) uzima kao gornja granica spremnosti za plaćanje od strane Fonda zdravstvenog osiguranja Srbije.

Ključne reči: Bajezijanska statistika, farmakoekonomske studije, inkrementalni odnos troškova i efektivnosti, procena 